\title{
Oral Pathologies in Subjects Living with HIV (PLHIV) At Campus University Hospital of Lomé \\ Palakina Agoda ${ }^{1 *}$, Attogbain Patrice Kouame ${ }^{2}$, Winga Foma ${ }^{3}$, Saliou Adam ${ }^{3}$, Abiré Kao ${ }^{1}$, Bina Betenora ${ }^{3}$, Bathokedeou Amana ${ }^{3}$ Yaotsè Anoumou Dagnra ${ }^{3}$, Eyawèlohn Kpemissi ${ }^{3}$
}

${ }^{1}$ Campus University Hospital (Lomé)

${ }^{2}$ Cocody University Hospital (Abidjan)

${ }^{3}$ Sylvanus Olympio University Hospital (Lomé)

DOI: $10.36347 /$ sjds.2021.v08i05.005

| Received: 19.04.2021 | Accepted: 31.05.2021 | Published: 15.06.2021

*Corresponding author: Dr. Palakina Agoda

Abstract

Original Research Article

Objective: To assess the dental care needs of people living with HIV who are regularly monitored at Campus University Hospital of Lomé. Method: This was a descriptive prospective survey conducted on patients followed regularly, from January 1 to December 31, 2016. Results: Our study involved 111 patients, 76.58\% of whom were female. The most represented age group was between 30 and 39 years old. Fourteen percent of the patients had a CD $4>500$ cell $/ \mathrm{mm} 3$ count and $37.5 \%$ of the lesions were seen in patients with WHO stage III HIV infection. Mucosal lesions were more common in subjects with low CD4 counts. Periodontitis represented 59.03\%, candidiasis $3.47 \%$. Seventy-six percent of the subjects required oral care. Conclusion: People living with HIV have a real need for oral health care. Systematic management of oral health care in in these subjects should improve their well-being and ensure them a life that is more balanced with their serological status.

Keywords: PLHIV, PLWHA, oral health, oral care, Togo.

Copyright $\odot 2021$ The Author(s): This is an open-access article distributed under the terms of the Creative Commons Attribution 4.0 International License (CC BY-NC 4.0) which permits unrestricted use, distribution, and reproduction in any medium for non-commercial use provided the original author and source are credited.

\section{INTRODUCTION}

Oral health is integral to general health and essential to quality of life [1]. The oral mucosa is fragile because it is easily exposed to bacterial, viral and mycological attacks which can cause a variation in its appearance. Certain systemic diseases such as diabetes, HIV infection or Crohn's disease lead to changes in the oral environment leading to the development of oral diseases [2].

Oral lesions associated with HIV are among the first manifestations to appear in people living with HIV (PLHIV), reaching prevalence rates ranging from 40 to $50 \%$ [1]. They can have diagnostic or predictive value and help monitor the course of infection in patients.

Several studies have described oral lesions associated with HIV infection, but very few have addressed the oral care needs of PLHIV [3]. In Togo, studies specifically evaluating the oral health care needs of PLHIV are non-existent.

As a result, there is no real integration of oral health into the care system for PLHIV. This observation is the main reason for this study, the general objective of which was to contribute to improving the access of PLHIV to quality oral health care. This specifically involved determining the prevalence of various oral diseases among PLHIV and assessing their needs for oral health care.

\section{PATIENTS AND METHOD}

This was a prospective, descriptive study in the odontostomatology service and the PLHIV care center at the Lomé Campus University Hospital, from January 1 to December 31, 2018.

\section{Inclusion criteria}

People whose retroviral serology was known to be positive for HIV and regularly treated for this status, and whose CD4 count was less than 6 months old and in permanent dentition, constituted our study sample.

The parameters studied were sociodemographic (sex, age, profession, residence), clinical (clinical stage, the individual Decayed, Missing and Filled Teeth (DMFT) Index, the prevalence of mucosal lesions, oral hygiene) or paraclinical (CD4 count). 


\section{Data collection and analysis technique}

The patients were recruited in the care and monitoring center for PLHIV of the Campus University Hospital according to their care program. After an awareness session on the need for a clinical oral examination, informed consent was obtained beforehand following tripartite counseling with the subject and the attending physician at the care center for an odontostomatological consultation. For ethical reasons the rules of confidentiality of the study were required. The data collected was processed using Microsoft Office 2010 Word and Excel software. About fifteen patients were asked to refuse to participate in the survey.

\section{RESULTS}

Out of 762 people living with HIV/AIDS (PLWHA) regularly monitored, 111 were concerned by our study, or $14.57 \%$. All of the 111 subjects were infected with the HIV1-like virus. Eighty-five subjects were female, ie $76.58 \%$. The sex ratio was 0.31 . The age of the subjects surveyed varied between the extremes of 12 and 63 years, and those whose age was between 30 and 39 years were the most represented $(36.94 \%)$. On the professional level, subjects without a fixed job represented $52.25 \%$ followed by trades people (27.93\%)
Clinical data

Their HIV status was associated with hypertension in $18.92 \%$ of cases, diabetes in $1.80 \%$ of cases, and $19.82 \%$ were used to alcohol and tobacco. Thirty-seven point five percent of the lesions have been observed in patients with WHO stage III HIV infection.

\section{CD4 count}

Almost $14 \%$ of our patients had a CD4>500 cells / mm3 count (Table I).

Table-I: Distribution of patients by CD4 count

\begin{tabular}{|l|l|l|}
\hline CD4 count $(/ \mathbf{m m 3})$ & Number & \% \\
\hline CD4 $<\mathbf{2 0 0}$ & 51 & 45.95 \\
\hline $\mathbf{2 0 0}<\mathbf{C D 4}<\mathbf{5 0 0}$ & 44 & 39.64 \\
\hline CD4 $>\mathbf{5 0 0}$ & 16 & 14.41 \\
\hline Total & $\mathbf{1 1 1}$ & $\mathbf{1 0 0}$ \\
\hline
\end{tabular}

Prevalence of oral lesions.

In the 111 patients followed, 144 lesions of the oral cavity were diagnosed. Periodontitis represented $77 \%$ of cases, candidiasis 5\% (Table II). There were 33 cases of oral manifestations in patients with a CD4 count $>500$ (Table III). The overall DMFT index presented by the 111 subjects in our sample was 3.48 .

Table-II: Distribution of patients according to their oral health compared to WHO clinical stages $(\mathrm{N}=144)$.

\begin{tabular}{|l|l|l|l|l|l|l|l|}
\hline & Gingivitis & $\begin{array}{l}\text { Mild } \\
\text { periodontitis }\end{array}$ & $\begin{array}{l}\text { Moderate } \\
\text { periodontitis }\end{array}$ & Candidiasis & Leukoplakia & Cheilitis & Caries \\
\hline Stage I & 1 & 9 & 2 & 1 & 0 & 0 & 13 \\
\hline Stage II & 3 & 18 & 1 & 1 & 0 & 0 & 10 \\
\hline Stage III & 0 & 37 & 2 & 2 & 0 & 2 & 11 \\
\hline Stage IV & 4 & 14 & 2 & 1 & 1 & 0 & 9 \\
\hline Total n(\%) & $8(5.56)$ & $78(54.17)$ & $7(4.86)$ & $5(3.47)$ & $1(0.69)$ & $2(1.39)$ & $43(29.86)$ \\
\hline
\end{tabular}

Table-III: Distribution of patients according to their oral health in relation to the CD4 count $(N=144)$.

\begin{tabular}{|l|l|l|l|l|l|l|l|}
\hline & Gingivitis & $\begin{array}{l}\text { Mild } \\
\text { periodontitis }\end{array}$ & $\begin{array}{l}\text { Moderate } \\
\text { periodontitis }\end{array}$ & Candidiasis & Leukoplakia & Cheilitis & Caries \\
\hline $\mathrm{CD} 4<200$ & 4 & 32 & 4 & 3 & 1 & 1 & 12 \\
\hline $200<\mathrm{CD} 4<500$ & 2 & 29 & 2 & 2 & 0 & 1 & 18 \\
\hline $\mathrm{CD} 4>500$ & 2 & 17 & 1 & 0 & 0 & 0 & 13 \\
\hline Total $\mathrm{n}(\%)$ & $8(5.56)$ & $78(54.17)$ & $7(4.86)$ & $5(3.47)$ & $1(0.69)$ & $2(1.39)$ & $43(29.86)$ \\
\hline
\end{tabular}

\section{Oral care needs}

In $13.51 \%$ of cases, the oral lesions observed did not require treatment (Table IV).

Table-IV: Distribution of patients according to their dental care needs $(\mathrm{N}=111)$

\begin{tabular}{|l|l|l|l|}
\hline Oral care needs & Number & $\%$ \\
\hline \multirow{3}{*}{ Caries treatment } & Dentin treatment & 9 & 8.11 \\
\cline { 2 - 4 } & Pulp care & 2 & 1.80 \\
\cline { 2 - 4 } & Tooth extractions & 23 & 20.72 \\
\hline & & & \\
\hline \multirow{2}{*}{ Periodontal treatment } & Descaling & 81 & 72.97 \\
\cline { 2 - 4 } & Periodontal pocket curettage & 5 & 4.50 \\
\hline \multicolumn{2}{|l|}{} & 18 & \\
\hline Mucosal care (drug treatment) & 21 & 16.22 \\
\hline Prosthetic care & 15 & 13.51 \\
\hline No treatment & & \\
\hline
\end{tabular}




\section{DISCUSSION}

This study enabled us to establish the oral health of a population of PLWHA in Togo, and to assess their needs for odontostomatological care. This was a static observation of the oral-dental situation, without highlighting any causal links between the specific immunological status of these subjects and the pathologies thus listed, or their degree of development. This is one of the limitations of this study which nevertheless has the merit, by evaluating the needs for oral health care among PLHIV in Togo, of posing the problem of an odontostomatological concern that is necessary or even essential for their care and follow-up, in order to ensure a more balanced life compatible with their serological status. The optimal care of PLHIV in Togo, should integrate, according to our study, the oral aspects of which the various socio-demographic and clinical determinants are to be considered in the overall file of the subject.

The female predominance of our sample is only a reflection of the general epidemiological profile of HIV infection in Togo [4]. This predominance could be explained not only by the high exposure of women to risk factors for HIV infection, but also by their greater motivation to participate in the various surveys. Our results are on this point, similar to those of neighboring Benin and Cameroon [5, 6].

The prevalence of dental pathologies and oral mucous membranes in PLHIV according to age groups would also be in line with the general trends mainly affecting young adults, the most represented in our study, being between 30 and 39 years old, and corroborating most of the findings. Literature work. These young layers are in fact more concerned by practices with a high risk of contamination by the AIDS virus [7-9].

Clinically, determinants reveal the exclusivity of our subjects' infection with HIV1, which is also very widespread in West and Central Africa with carrier rates varying between $68 \%$ and $99 \%$, both among children than adults [10-14].

Studies with a specific method, the objective of which would be to search for possible causal links between the oral pathologies recorded, their mode of development and the serological status would make it possible to better elucidate the question of oral diseases of the subject PLHIV.

The highest proportions of oral and dental pathologies, in particular mucous membranes, in this study were located at a CD4 count of less than 200 / $\mathrm{mm} 3$. This is the case with periodontitis, candidiasis, leukoplakia and cheilitis. This result could give particular importance to the CD4 count as a significant determinant of the condition of the oral mucosa of the subject PLHIV.

Dental caries, for its part, does not seem to be linked to the CD4 count and / or to the clinical stage in our study, as some studies have already observed in the literature [15].

By their nature and prevalence, oral diseases of PLHIV should deserve special attention in the process of their monitoring and management. Mucosal pathologies seem in their evolution to be more related to their immunological status. Oral candidiasis, which is recognized in the literature as the most frequent manifestations, occupied a relatively low proportion in this study [16]. This low proportion should be put into perspective because of the effective intake of current ARVs by all of the subjects in our sample.

At the dental level, the CAO index of 3.48 measuring the state of dental health is average and therefore does not present a significant difference with that found in a hospital study on dental caries in the same study framework [17].

In view of the pathological picture, PLWHA therefore have a significant need for periodontal, mucous membrane and dental treatments, which are necessary and essential to limit the occurrence of opportunistic oral pathologies, in order to lead a balanced life compatible with their immunological status.

\section{CONCLUSION}

Paying more attention to oral care in all care and monitoring programs for PLWHA would improve their state of health and well-being and ensure them a more balanced life, compatible with their HIV status.

\section{REFERENCES}

1. OMS. (2018). Santé bucco-dentaire [En ligne]. [Consulté le 20/12/2018]. Disponible : https://www.who.int/fr/news-room/factsheets/detail/oral-health

2. Gandolfo, S., Scully, C., Carrozzo, M. (2006). Oral Medicine. Elsevier Health Sciences.

3. Tetmoun, A., Benoist, H.M., Diallo, P.D., Bengondo, C. (2006). Etat parodontal et infection par le VIH; Thèse : chir. Dent: Dakar; 32.

4. Programme national de lutte contre le SIDA et les IST. (2016). Rapport annuel d'activités. Lomé : PNLS-IST.

5. Mattout, P., \& Mattout, C. (2003). Les thérapeutiques parodontales et implantaires. Quintessence international.

6. Tetmoun, A., Benoist, H.M., Diallo, P.D., Bengondo, C. (2006). Etat parodontal et infection par le VIH; Thèse : chir. Dent. : Dakar; 32. 
7. Gaye, A. (1993).Manifestations buccales au cours du SIDA, valeur prédictive. Facteurs étiologiques de risque. Thèse; Chir. Dent: Dakar, $\mathrm{n}^{\circ} 08$.

8. Ndiaye, T. A. B. (1996). Les manifestations buccales et le statut immunologique au cours de l'infection à VIH. Thèse; Chir. Dent : Dakar, ${ }^{\circ} 72$.

9. Zing, S. (1999). Manifestations parodontales et VIH: étude épidémiologique préliminaire, castémoins à l'hôpital central de Yaoundé. Thèse; Chir. Dent : Dakar, 11

10. Pilly, E. (2006). Maladies infectieuses et tropicales, 21e éd. Vivactis, Paris.

11. Okome-Nkoumou, M., Mbounja-Loclo, M. E., \& Kombila, M. (2000). Panorama des affections opportunistes au cours de l'infection par le VIH à Libreville, Gabon. Cahiers d'études et de recherches francophones/Santé, 10(5), 329-37.

12. N'Doye, Y. (2004). Caractéristiques cliniques parodontales chez les PVVIH : à propos de 86 cas observés à Dakar (clinique des maladies infectieuses du CHU de Fann). Thèse de Chirurgie dentaire, 25, Dakar, Sénégal.

13. Loggouet, A.B. (2004). Infection à VIH: prise en charge des manifestations. A propos de 75 cas colligés à l'hôpital principal de Dakar. Thèse de Chirurgie dentaire 2004, $\mathrm{n}^{\circ} 18$, Dakar, Sénégal

14. Mbaye. I. (2003). Etude des manifestations buccales au cours du sida chez l'enfant au Sénégal. Thèse de Chirurgie dentaire, 25, Dakar, Sénégal

15. Santé bucco-dentaire et VIH. consultas@gttvih.org

16. Ntima-Nsiemi, K., Mangyanda, M. K., Mbuila, C., ON'OKOKO, B. B., \& Attar, A. (2000). Sida et infection à VIH en stomatologie. littérature, 1(4), 5.

17. Agoda, P., Hemou, P., Betenora, B., Amana, B., Komi, A.M., Boko, E. (2015). Aspects épidémiologiques et cliniques de la carie dentaire au CHU-Campus de Lomé (Togo). J. Rech. Sci. Univ. Lomé;17 (2) ; 451-62. 